\title{
An unusual incidence of Donepezil-induced exacerbation in Parkinsonian features in a known case of Dementia: a case report
}

\author{
Sayantani Mukherjee \\ Consultant Psychiatrist, Department of Psychiatry, Chaitanya Institute for Mental Health \\ Corresponding author: Sayantani Mukherjee \\ Email-drsayantani25@gmail.com
}

\begin{abstract}
A 72-year old lady, known case of Alzheimer's disease (AD), with Dementia with Behavioral Disturbance (DBD) and Parkinson's Disease (PD), had erroneously received $43 \mathrm{mg} /$ day of donepezil for 7 days instead of her regular dosage of $20 \mathrm{mg} /$ day. She presented with rapid-onset global rigidity and subsequent altered sensorium. She was diagnosed with Metabolic Encephalopathy and acute exacerbation of PD in a known case of $\mathrm{AD}, \mathrm{DBD}$ and PD. MRI brain revealed no acute changes. She was monitored in ICU set-up, given supportive and symptomatic treatment; her anti-parkinsonian regime was stepped up and she recovered completely in 14 days. As per literature, as no other attribution for the rigidity was plausible after an extensive neuro-psychiatric investigation, this is postulated to be a rare presentation of acute exacerbation of PD brought on by excessive doses of donepezil in an existing case of dementia with PD.
\end{abstract}

Key words: Donepezil, acetylcholinesterase inhibitors, drug-induced parkinsonism, striatum, Parkinson's Disease, dementia

(Paper received $-10^{\text {th }}$ March 2020 , Peer review completed $-17^{\text {th }}$ March 2020 )

(Accepted $-20^{\text {th }}$ March 2020)

\section{INTRODUCTION}

Adverse drug reactions (ADRs) of donepezil i.e. acetylcholinesterase inhibitor (AchEI), especially when taken in excess of recommended dosages, commonly entail nausea, vomiting, bradycardia, flaccidity of muscles, increased secretions, respiratory depression and occasionally, seizures; parkinsonian features are generally not found [1]. A rare case of acute exacerbation in Parkinsonian symptoms after a rapid increase in dose of donepezil is being reported below. It has implications in management of common geriatric/ neuropsychiatric diagnoses of co-morbid dementia and Parkinson's disease (PD).

\section{CASE REPORT}

A 72 years old lady, a diagnosed case of Alzheimer's disease (AD) [ICD G30.9] - moderate severity on Clinical Dementia Rating Scale [CDRS], Dementia with Behavioral Disturbance (DBD) [ICD F03.91] and Parkinson's Disease (PD) [ICD G20] has been following up in out-patient department for 2 years. She was seen monthly by both Psychiatry and Neurology services in liaison, and has been symptomatically stable since last 18 months. In last 6 months, she was well-maintained on oral tablets of Levodopa+ Carbidopa $110 \mathrm{mg}$ BD, Donepezil 10mg BD, Quetiapine $12.5 \mathrm{mg}$ HS, Sertraline $12.5 \mathrm{mg}$ OD and Clonazepam 0.5mg SOS for insomnia (which would be used 2-3 times/ month). Her pre-morbid SCOPA-MF [Scales for Outcomes in Parkinson's Disease - Motor Functions] score was 19, placing her symptoms in the mild range. She was hypertensive and type 2 diabetic, maintained on Telmisartan 40mg and Metformin 500mg per day. 
With the intention to boost her memory, the family had procured donepezil CR tablets $23 \mathrm{mg}$ at advice of their family physician. Without consulting psychiatrist or neurologist, they added this on as one tablet HS dose to the earlier mentioned prescription. Due to difference in brand names, the family said they had no idea they were overmedicating with the same molecule. After 5 days, the patient developed rigidity all over body which increased over the next 2 days and patient became incapable of doing her activities of daily living, sitting up, turning over in bed or opening her mouth to ingest nourishment. She became increasingly unresponsive after which she was brought into the emergency department and admitted into ICU set-up. Regular medications had been omitted from 1 day prior to admission due to difficulty in oral administration and she was only being given liquid diet at home since the past 3 days.

She was treated in liaison with general medicine and neurology services [see tables 1 and 2].

Table 1: SCOPA-MF [Scales for Outcomes in Parkinson's disease - Motor Functions]

\begin{tabular}{|c|c|c|c|c|c|c|}
\hline COMPONENTS & DAY 1 (DoA) & DAY 3 & DAY 5 & DAY 7 & DAY 11 & DAY $14(\mathrm{DoD})$ \\
\hline \multicolumn{7}{|c|}{ A: MOTOR EVALUATION } \\
\hline A1. Rest Tremors & 2 & 2 & 2 & 2 & 2 & $1 \downarrow$ \\
\hline A2. Postural Tremors & 2 & 2 & 2 & $1 \downarrow$ & 1 & $0 \downarrow$ \\
\hline $\begin{array}{l}\text { A3. Rapid Alternating } \\
\text { Hand Movements }\end{array}$ & 3 & 3 & 3 & $2 \downarrow$ & $1 \downarrow$ & 1 \\
\hline A4. Rigidity & 3 & $2 \downarrow$ & 2 & 2 & $1 \downarrow$ & $0 \downarrow$ \\
\hline A5. Rise from Chair & 3 & 3 & 3 & $2 \downarrow$ & $1 \downarrow$ & $0 \downarrow$ \\
\hline A6. Postural Instability & 3 & $2 \downarrow$ & 2 & 2 & $1 \downarrow$ & $0 \downarrow$ \\
\hline A7. Gait & 3 & 3 & 3 & 3 & $2 \downarrow$ & 1 \\
\hline A8. Speech & 3 & 3 & 3 & $2 \downarrow$ & $\overline{1 \downarrow}$ & $\overline{0 \downarrow}$ \\
\hline A9. Freeze 'On' & 3 & 3 & 3 & 3 & $2 \downarrow$ & $1 \downarrow$ \\
\hline A10. Swallowing & 3 & 3 & 3 & $2 \downarrow$ & $1 \downarrow$ & $0 \downarrow$ \\
\hline A TOTAL & 28 & 26 & 26 & 21 & 13 & 4 \\
\hline \multicolumn{7}{|c|}{ B: ACTIVITES OF DAILY LIVING } \\
\hline B11. Speech & 3 & 3 & 3 & $2 \downarrow$ & $1 \downarrow$ & $0 \downarrow$ \\
\hline B12. Feeding & 3 & 3 & 3 & 3 & $1 \downarrow$ & $0 \downarrow$ \\
\hline B13. Dressing & 3 & 3 & 3 & 3 & $2 \downarrow$ & $1 \downarrow$ \\
\hline B14. Hygiene & 3 & 3 & 3 & 3 & $2 \downarrow$ & $1 \downarrow$ \\
\hline B15. Changing Positions & 3 & 3 & 3 & $2 \downarrow$ & $1 \downarrow$ & $0 \downarrow$ \\
\hline B16. Handwriting & 3 & 3 & 3 & 3 & $2 \downarrow$ & $1 \downarrow$ \\
\hline B17. Handwriting & 3 & 3 & 3 & 3 & $1 \downarrow$ & 1 \\
\hline B TOTAL & 21 & 21 & 21 & 19 & 10 & 4 \\
\hline \multicolumn{7}{|c|}{ C: MOTOR COMPLICATIONS } \\
\hline C18. Dyskinesia (presence) & 3 & 3 & 3 & $2 \downarrow$ & $1 \downarrow$ & $0 \downarrow$ \\
\hline C19. Dyskinesia (severity) & 2 & 2 & 2 & 2 & $1 \downarrow$ & $0 \downarrow$ \\
\hline $\begin{array}{l}\text { C20. Motor Worsening } \\
\text { (Presence) }\end{array}$ & 3 & 3 & 3 & $2 \downarrow$ & $1 \downarrow$ & 1 \\
\hline $\begin{array}{l}\text { C21. Motor Worsening } \\
\text { (Severity) }\end{array}$ & 2 & 2 & 2 & 2 & $1 \downarrow$ & 1 \\
\hline C TOTAL & 10 & 10 & 10 & 8 & 4 & 2 \\
\hline $\begin{array}{l}\text { UPDRS-ME Converted } \\
\text { Total Score and Severity }\end{array}$ & 79; Severe & 74 ; Severe & 74; Severe & 62; Severe & 43;Moderate & 21; Mild \\
\hline
\end{tabular}

\section{DISCUSSION}

The diagnosis of this case was much debated as the hyponatremic encephalopathy could not account for the global rigidity and the extent of drowsiness even after correcting the serum sodium levels. There was no 
other gross or focal neurological finding except for the global rigidity. Also, the patient improved with higher dose of anti-parkinsonian drugs and history of symptoms being brought on after the higher doses of donepezil. Thus, the rapid increase in donepezil doses as causality was focused upon. Assessment on 2 widely used tools for ADRs - Naranjo Algorithm score was 9 (interpretation: definite ADR) [see table 3] and Hartwig's Severity Assessment Scale showed level 5 severity (interpretation: the suspected drug had to be discontinued, and antidote/ other treatment along with hospital admission and intensive medical care was required to treat the ADR) [5].

Table 3: Naranjo Algorithm ***

\begin{tabular}{|c|c|}
\hline Parameter & Score \\
\hline 1. Are there previous conclusive reports on this reaction? & +1 (yes) \\
\hline 2. Did the adverse reaction occur after the suspected drug was administered? & +2 (yes) \\
\hline $\begin{array}{l}\text { 3. Did the adverse reaction improve when the drug was discontinued or a specific } \\
\text { antagonist was administered? }\end{array}$ & +1 (yes) \\
\hline 4. Did the adverse reaction reappear when the drug was readministered? & 0 (don't know) \\
\hline $\begin{array}{l}\text { 5. Are there alternative causes that could have on their own have caused the } \\
\text { reaction? }\end{array}$ & +2 (no) \\
\hline 6. Did the reaction reappear when a placebo was given? & +1 (no) \\
\hline $\begin{array}{l}\text { 7. Was the drug detected in blood (or other fluids) in concentrations known to be } \\
\text { toxic? }\end{array}$ & 0 (don't know) \\
\hline $\begin{array}{l}\text { 8. Was the reaction more severe when the dose was increased or less severe when } \\
\text { the dose was decreased? }\end{array}$ & +1 (yes) \\
\hline $\begin{array}{l}\text { 9. Did the patient have a similar reaction to the same drug in any previous } \\
\text { exposure? }\end{array}$ & 0 (don't know) \\
\hline 10. Was the adverse event confirmed by any objective evidence? & +1 (yes) \\
\hline TOTAL SCORE & 9 (definite ADR) \\
\hline
\end{tabular}

Donepezil toxicity could also not be ruled out, as US-FDA recommended doses of donepezil and donepezil $\mathrm{CR}$ are $20 \mathrm{mg} /$ day and $23 \mathrm{mg}$ /day for moderate to severe dementias. However, it was excluded from final diagnosis as, except for excessive drowsiness and CNS hypo-responsiveness, the telling signs of donepezil toxicity - vomiting, excessive secretions, diaphoresis, respiratory depression and bradycardia, which all occur due to cholinergic overstimulation, were absent [1].

An extensive literature search resulted in one similar previously reported case - also an elderly woman, diagnosed case of $\mathrm{AD}$, who had acute motor parkinsonian symptoms after a rapid increase in the dose (by $\geq 7 \mathrm{mg}$ / day, increased overnight) of ongoing donepezil. Her symptoms onset was within 14 days - in form of global rigidity, total loss of ADL and deteriorated sensorium and cognition. She recovered to premorbid states after temporarily withdrawing donepezil, aggressively treating PD and strict monitoring in an ICU set-up. Donepezil was reintroduced into treatment in lower doses without causing any recurrence in acute PD symptoms. However, a re-challenge with rapid increase in dose/ higher doses wasn't given [6]. Onset of symptoms in this case follows the same pattern except it was faster, possibly due to much higher increase in dose.

Another case report was found where rapidly increased donepezil had led to hyponatremia and hyponatremia-induced seizures. In this case, patient was not given a re-challenge with donepezil after recovery. Though the hyponatremia in this case was most likely multi-factorial, the higher doses of donepezil could have been a contributory cause [7].

Donepezil is an acetylcholinesterase inhibitor (AchEI) i.e. it inhibits the enzyme acetylcholinesterase and increases levels of acetylcholine (Ach) in the neural synapses. In cerebral cortex, Ach enhances memory encoding by influencing feed-forward afferent inputs to cortex, increasing cortical response to specific 
features of sensory stimuli while decreasing excitatory feedback interference (i.e. improves signal: noise ratio) [8]. In striatum, Ach releasing interneurons have complex functions - mediating movements, memory, REM sleep, alertness and activity levels by working in conjunction with NMDA and GABA releasing neuronal systems [9].

AchEIs have different affinities for different isoforms of AchE. Out of them, G1 AchE mediates memory and sensory modulation while G4 AchE is closely linked to movement and alertness. Donepezil has high affinity for both G1 and G4 isoforms. But previous studies on animal models have shown that in striatum, donepezil displays far more affinity for G4 AchE as compared to G1 AchE [10]. A human study found that, as a function of aging, the G4:G1 concentration increases to 21:1 in striatum and 1.7:1 in temporal cortex [11]. Therefore, the movement modulating AchE is overall far more available in the aged human brain than the memory modulating isoform, and most so in striatum. So, it can be postulated, that symptoms in the above patient have arisen due to (a) excess donepezil quantity, (b) higher selective action on G4 isoform causing motor movement slowing (c) existing PD, where the NMDA receptors would be more vulnerable to firing with more acetylcholine, and weakening inhibitory mechanisms, overall resulting in increased motor parkinsonian features. Also, a query remains whether there is truly a female predisposition for these manifestations, or whether so far both cases being female is an incidental finding. Co-morbid PD with dementia incidence, prevalence, symptom severity and degeneration at receptor level are all known to be more in males. But a review article states that female brains express more oestrogen receptors in basal forebrain, which have a trophic effect on cholinergic neurons and amplify the action of cholinergic systems of those areas; that could explain why females were more likely affected [12]. Furthermore, it might be noteworthy to wonder about genetic predisposition in certain demographics- as all the cases discussed here are aetio-pathologically AchEI-induced ADRs that are not amounting to cholinergic toxicity - are reports of Indian and Southeast-Asian geriatric/ near-geriatric persons. However, at present, both of these are inexact postulations owing to lack of sufficient data, so they remain open for exploration through further case reporting/ epidemiological and longitudinal studies.

The lack of symptoms of cholinergic toxicity also needs to be accounted for. It could be that while the donepezil overdose affected the more vulnerable striatal G4 AchE and increased Ach concentration in those synapses, the dose was not large enough to affect all isoforms of AchE on such a large scale as to bring on global parasympathetic hyperstimulation that would result in clinical symptoms. A case report of a 53 years old male having donepezil overdose cites that symptoms of cholinergic toxicity only manifested when the patient received an overdose (200mg of donepezil/ 24 hours) which is ten times the daily recommended dose [1], whereas this patient had received about twice the recommended daily dose.

Management, in the previous reported case and here too, was supportive, symptomatic and directed towards aggressively managing parkinsonism. As the half-life of donepezil is long (approximately 70 hours), perhaps that is why it took the patient approximately 11 days to show significant improvement, as it takes around 4 -5 half-lives for the drug to be systemically eliminated [13]. This also points to iatrogenic etiology i.e. the donepezil overdose, and the recovery arc of the patient is comparable to that of the previous case report.

Cases such as this can raise the question of the long-term prognosis of dementia patients with concurrent $\mathrm{PD}$ receiving donepezil, and whether its long term cumulation can worsen parkinsonian features. A Japanese pooled analysis monitoring such patients on therapeutic doses of donepezil over 52 weeks finds no such risks so far [14].

Though this is a rare occurrence, it is always beneficial for clinicians, especially those working in geriatric and neuropsychiatry, to be knowledgeable of such uncommon iatrogenic etiopathogenesis and presentation, so as to (a) be careful while titrating donepezil/ other AchEI doses in vulnerable population i.e. cases of concomitant $\mathrm{AD}$ and $\mathrm{PD}$ (especially females, going by the current data), as well as (b) being able to administer more delineated treatment in such cases that can lead to good outcome in terms of patient recovery.

NOTE: Written consent has been taken from patient and family for publication of this case report on condition that no identifying information will be disclosed. Requisite permissions have been taken for using scales. 


\section{REFERENCES}

1. Shepherd G, Klein-Schwartz W, Edwards R. Donepezil overdose: a tenfold dosing error. Ann Pharmacother 1999;33(7-8):812-5.

2. Reith FC, Van den Brande R, Synnot A, Gruen R, Maas AI. The reliability of the Glasgow Coma Scale: a systematic review. Intens Care Med 2016;42(1):3-15.

3. Marinus J, Visser M, Stiggelbout AM, Rabey JM, Martínez-Martín P, Bonuccelli U, Kraus PH, van Hilten JJ. A short scale for the assessment of motor impairments and disabilities in Parkinson's disease: the SPES/SCOPA. J Neurol Neurosurg Psychiatry 2004;75(3):388-95.

4. Verbaan D, Van Rooden SM, Benit CP, van Zwet EW, Marinus J, van Hilten JJ. SPES/SCOPA and MDSUPDRS: formulas for converting scores of two motor scales in Parkinson's disease. Parkinson Rel Disord 2011;17(8):632-4.

5. Palanisamy S, Kumaran KS, Rajasekaran A. A study on assessment, monitoring and reporting of adverse drug reactions in Indian hospital. Asian J Pharm Clin Res 2011;4(3):112-6.

6. Rangseekajee P, Paholpak S, Aphisitphinyo S, Pimpanit V, Paholpak P. Severe medication-induced parkinsonism from a higher dose of donepezil $(23 \mathrm{mg} /$ day $)$ in early-onset Alzheimer's disease. Eur Neuropsychopharmacol 2016;2(26):S646-51.

7. Shareef J, Joseph J, Adithi K. A single case report on hyponatremia seizure induced by acetylcholinesterase inhibitors. Int J Pharm Pharmaceut Sci 2017;9:165-6.

8. Hasselmo ME. The role of acetylcholine in learning and memory. Curr Opin Neurobiol 2006;16(6):710-5.

9. Calabresi P, Centonze D, Gubellini P, Pisani A, Bernardi G. Acetylcholine-mediated modulation of striatal function. Trends Neurosci 2000;23(3):120-6.

10. Zhao Q, Tang XC. Isolation of acetylcholinesterase G4 and G1 molecular isoforms from rat cortex. Acta Pharmacol Sin 2002;23(2):173-6.

11. Atack JR, Perry EK, Bonham JR, Candy JM, Perry RH. Molecular forms of acetylcholinersterase and butyrylcholinesterase in the aged human central nervous system. J Neurochem 1986;47(1):263-77.

12. Giacobini E, Pepeu G. Sex and gender differences in the brain cholinergic system and in the response to therapy of Alzheimer disease with cholinesterase inhibitors. Curr Alzheim Res 2018;15(11):1077-84.

13. Stahl SM. Essential psychopharmacology: the prescriber's guide. Cambridge University Press; 2005.

14. Mori E, Ikeda M, Nakagawa M, Miyagishi H, Yamaguchi H, Kosaka K. Effects of donepezil on extrapyramidal symptoms in patients with dementia with Lewy bodies: a secondary pooled analysis of two randomized-controlled and two open-label long-term extension studies. Dement Geriatr Cogn Disord 2015;40(3-4):186-98.

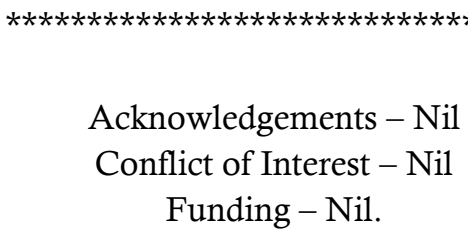


Table 1: Management

\section{REFERRALS}

General medicine: hyponatremia treated; continue medications for hypertension and diabetes type 2 with monitoring on SOS basis

Neurology: global rigidity - likely exacerbation of PD motor symptoms; stepped up PD treatment

Physiotherapy: passive and later active mobilization and assisted ambulation done

\section{INVESTIGATIONS}

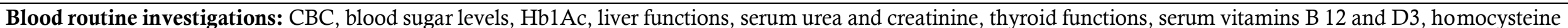
levels were all within normal limits

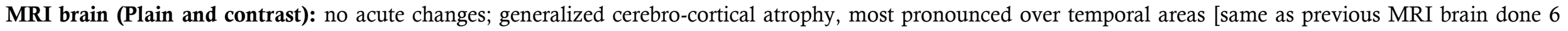
months earlier]

CSF: routine, microscopy and culture: no abnormalities detected

EEG: mostly alpha, theta interspersed with some delta activity; of no diagnostic significance as opined by neurologist

Specific blood and CSF investigations for autoimmune/ organic encephalopathies: no positive findings

Serum donepezil levels: not estimated due to non-availability of facilities

\section{DIAGNOSIS}

Metabolic Encephalopathy [ICD G93.41] and Acute Exacerbation of Dementia with Parkinsonism [ICD G 31.83] in a known case of AD [ICD G30.9], DBD [ICD F03.91] and PD [ICD G20]

\begin{tabular}{|c|c|c|c|c|c|c|}
\hline \multicolumn{7}{|c|}{ MANAGEMENT IN IPD } \\
\hline Condition & Day 1 (DoA) & Day 3 & Day 5 & Day 7 & Day 11 & Day 14 (DoD) \\
\hline $\begin{array}{l}\text { Sensorium } \\
(\text { by GCS*) }\end{array}$ & $\begin{array}{l}\text { E1M4V1 } \\
\leq 8: \text { severe }\end{array}$ & $\begin{array}{l}\text { E1M4V1 } \\
\leq 8: \text { severe }\end{array}$ & $\begin{array}{l}\text { E1M4V1 } \\
\leq 8: \text { severe }\end{array}$ & $\begin{array}{l}\text { E3M6V2 } \\
\text { 11: moderate }\end{array}$ & $\begin{array}{l}\text { E4M6V3 } \\
\text { 13: mild }\end{array}$ & $\begin{array}{l}\text { E4M6V5 } \\
\text { 15: normal }\end{array}$ \\
\hline $\begin{array}{l}\text { Rigidity } \\
\text { (by SCOPA-MF** converted } \\
\text { to UPDRS-ME score) }\end{array}$ & $\begin{array}{l}79 \\
\text { Severe }\end{array}$ & $\begin{array}{l}74 \\
\text { Severe }\end{array}$ & $\begin{array}{l}74 \\
\text { severe }\end{array}$ & $\begin{array}{l}62 \\
\text { severe }\end{array}$ & $\begin{array}{l}43 \\
\text { moderate }\end{array}$ & $\begin{array}{l}21 \\
\text { mild }\end{array}$ \\
\hline Serum sodium levels & $118 \mathrm{mEq} / \mathrm{L}$ & $129 \mathrm{mEq} / \mathrm{L}$ & $136 \mathrm{mEq} / \mathrm{L}$ & $136 \mathrm{mEq} / \mathrm{L}$ & $135 \mathrm{mEq} / \mathrm{L}$ & $138 \mathrm{mEq} / \mathrm{L}$ \\
\hline Clinical findings & $\begin{array}{l}\mathrm{T}, \mathrm{BP}, \mathrm{RR}, \mathrm{HR}, \\
\mathrm{SpO}_{2} \text { normal } \\
\text { Unresponsive to } \\
\text { verbal stimuli, } \\
\text { responding }\end{array}$ & $\begin{array}{l}\mathrm{T}, \mathrm{BP}, \mathrm{RR}, \mathrm{HR}, \\
\mathrm{SpO}_{2} \text { normal } \\
\text { No change in } \\
\text { alertness, rigidity } \\
\text { mildly decreased }\end{array}$ & $\begin{array}{l}\mathrm{T}, \mathrm{BP}, \mathrm{RR}, \mathrm{HR}, \\
\mathrm{SpO}_{2} \text { normal } \\
\text { No change in } \\
\text { alertness or rigidity }\end{array}$ & $\begin{array}{l}\mathrm{T}, \mathrm{BP}, \mathrm{RR}, \mathrm{HR}, \\
\mathrm{SpO}_{2} \text { normal } \\
\text { Can open mouth } \\
\text { and swallow, move } \\
\text { all } 4 \text { limbs }\end{array}$ & $\begin{array}{l}\mathrm{T}, \mathrm{BP}, \mathrm{RR}, \mathrm{HR}, \mathrm{SpO}_{2} \\
\text { normal } \\
\text { Alert, sitting up and } \\
\text { ambulating with } \\
\text { support, feeding }\end{array}$ & $\begin{array}{l}\mathrm{T}, \mathrm{BP}, \mathrm{RR}, \mathrm{HR}, \mathrm{SpO}_{2} \\
\text { normal } \\
\text { Back to premorbid } \\
\text { condition }\end{array}$ \\
\hline
\end{tabular}




\begin{tabular}{|c|c|c|c|c|c|c|}
\hline & $\begin{array}{l}\text { sluggishly to } \\
\text { pain, global } \\
\text { rigidity } \\
\text { Mild } \\
\text { dehydration } \\
\text { Reduced urine } \\
\text { output }\end{array}$ & $\begin{array}{l}\text { Hydration } \\
\text { improved Urine } \\
\text { output normal }\end{array}$ & & $\begin{array}{l}\text { spontaneous, follow } \\
\text { 1-step verbal } \\
\text { command }\end{array}$ & $\begin{array}{l}\text { orally. Attention } \\
\text { aroused, mostly well } \\
\text { oriented, Incoherent } \\
\text { responses with } \\
\text { slurring of speech }\end{array}$ & \\
\hline Management & $\begin{array}{l}\text { Initial bolus of } \\
\text { dose of } 100 \mathrm{ml} \\
3 \% \mathrm{NaCl} \\
\text { After initial } \\
\text { bolus, slow } \\
\text { sodium } \\
\text { correction at } \\
6 \mathrm{mEq} / \text { lit } \\
\text { Levodopa }+ \\
\text { Carbidopa } \\
110 \mathrm{mg} \text { TDS } \\
\text { Levodopa CR } \\
250 \mathrm{mg} \text { OD } \\
\text { Tolvaptan } 10 \mathrm{mg} \\
\text { OD } \\
\text { Clonazepam } \\
\text { 0.5mg } 1 \text { tablet } \\
\text { SOS for poor } \\
\text { sleep } \\
\text { IV fluids } \\
\text { Monitoring vitals } \\
\text { and strict input- } \\
\text { output charting } \\
\text { Nourishment } \\
\text { through } \\
\text { nasogastric tube. }\end{array}$ & $\begin{array}{l}\text { Continued slow } \\
\text { sodium correction } \\
\text { at } 6 \mathrm{mEq} / \text { lit } \\
\text { Levodopa + } \\
\text { Carbidopa } 110 \mathrm{mg} \\
\text { TDS } \\
\text { Levodopa CR } \\
250 \mathrm{mg} \text { OD } \\
\text { Tolvaptan } 10 \mathrm{mg} \\
\text { OD } \\
\text { Clonazepam } \\
0.5 \mathrm{mg} 1 \text { tablet } \\
\text { SOS for poor sleep } \\
\text { IV fluids } \\
\text { Monitoring vitals } \\
\text { and strict input- } \\
\text { output charting } \\
\text { Nourishment } \\
\text { through } \\
\text { nasogastric tube. }\end{array}$ & $\begin{array}{l}\text { Continued slow } \\
\text { sodium correction } \\
\text { at } 6 \mathrm{mEq} / \text { lit } \\
\text { Levodopa + } \\
\text { Carbidopa } 110 \mathrm{mg} \\
\text { TDS } \\
\text { Levodopa CR } \\
250 \mathrm{mg} \text { BD (dose } \\
\text { increased) } \\
\text { Trihexyphenidyl } 1 \\
\text { mg TDS (added) } \\
\text { Tolvaptan 10mg } \\
\text { OD } \\
\text { Clonazepam } \\
0.5 \text { mg } 1 \text { tablet } \\
\text { SOS for poor sleep } \\
\text { IV fluids } \\
\text { Monitoring vitals } \\
\text { and strict input- } \\
\text { output charting } \\
\text { Nourishment } \\
\text { through } \\
\text { nasogastric tube. }\end{array}$ & $\begin{array}{l}\text { Levodopa }+ \\
\text { Carbidopa } 110 \mathrm{mg} \\
\text { TDS } \\
\text { Levodopa CR } \\
\text { 250mg BD } \\
\text { Trihexyphenidyl } 1 \\
\text { mg TDS } \\
\text { Amantidine 100mg } \\
\text { TDS (added) } \\
\text { Tolvaptan 10mg OD } \\
\text { Clonazepam 0.5mg } \\
1 \text { tablet SOS for } \\
\text { poor sleep } \\
\text { IV fluids } \\
\text { Monitoring vitals } \\
\text { and strict input- } \\
\text { output charting } \\
\text { Nourishment } \\
\text { through nasogastric } \\
\text { tube. }\end{array}$ & $\begin{array}{l}\text { Levodopa }+ \\
\text { Carbidopa } 110 \mathrm{mg} \\
\text { TDS } \\
\text { Levodopa CR } 250 \mathrm{mg} \\
\text { OD } \\
\text { Trihexyphenidyl } 1 \mathrm{mg} \\
\text { TDS } \\
\text { Amantidine } 100 \mathrm{mg} \\
\text { TDS } \\
\text { Tolvaptan } 10 \mathrm{mg} \text { OD } \\
\text { Clonazepam } 0.5 \mathrm{mg} 1 \\
\text { tablet SOS for poor } \\
\text { sleep } \\
\text { IV fluids } \\
\text { Shifted to oral feed } \\
\text { Physiotherapy } \\
\text { initiated } \\
\text { Shifted from ICU to } \\
\text { wards }\end{array}$ & $\begin{array}{l}\text { Levodopa + Carbidopa } \\
\text { 110mg TDS } \\
\text { Levodopa CR 250mg } \\
\text { OD } \\
\text { Trihexyphenidyl } 1 \mathrm{mg} \\
\text { TDS } \\
\text { Amantidine } 100 \mathrm{mg} \\
\text { TDS } \\
\text { Tolvaptan 10mg OD } \\
\text { Clonazepam 0.5mg } 1 \\
\text { tablet SOS for poor } \\
\text { sleep } \\
\text { Physiotherapy }\end{array}$ \\
\hline
\end{tabular}




\section{POST-DISCHARGE OPD FOLLOW-UP}

\section{After 7 days of discharge:}

Features of dementia, concomitant behavioural symptoms, insomnia resurfaced: restarted on Donepezil 5 mg, Sertraline 12.5 mg and Quetiapine 12.5 mg; Amantadine tapered to $100 \mathrm{mg} \mathrm{BD}$.

\section{After 15 days of discharge:}

Donepezil increased to 10mg i/v/o dementia; no exacerbation in PD; Amantadine tapered to 100mg OD.

\section{After 30 days of discharge:}

Donepezil increased to $20 \mathrm{mg}$ i/v/o dementia; no exacerbation of PD; Amantidine tapered off.

After 5 months of discharge (latest follow-up):

Well-maintained on oral Levodopa + Carbidopa 110mg BD, Levodopa CR 250mg OD, Quetiapine 12.5 mg HS and Clonazepam 0.5mg 1 tab SOS for poor sleep

(virtually similar to her prescription before this episode). Her sodium levels are normal, and her GCS and SCOPA-MF scores are maintained at the same levels since

discharge. Her dementia severity on CDRS remains moderate.

*GCS = Glasgow Coma Scale: well-established neurological scale used globally in clinical and research setting for assessment of the state of a person's

consciousness; reliability $>0.8$, validity $0.79-0.97$. Interpretation of impairment in consciousness: $\leq 8$ : severe, 9-12: moderate, $\geq 13$ : mild. [2]

**SCOPA-MF = Scales for Outcomes in Parkinson's Disease - Motor Functions; 21 item scale, each with 0-3 rating from least to most severe; reliability: 0.7-0.9, validity:0.86-0.95. Scoring: There is no quantitative cut-off so to calculate significant reduction over a period of time for a certain patient, the most widely used method is to convert the SCOPA-MF motor evaluation score to UPDRS-ME [Unified Parkinson's Disease Rating Scale-Motor Examination; reliability: 0.82-0.87, validity $0.78-0.91]$ scores using formula 'UPDRS-ME score $=11.8+2.4$ * SCOPA-MF motor evaluation score' and then UPDRS-ME interpretation is applied [impairment level: 0-32: mild; 33-58: moderate; >59: severe]. [3,4] 